
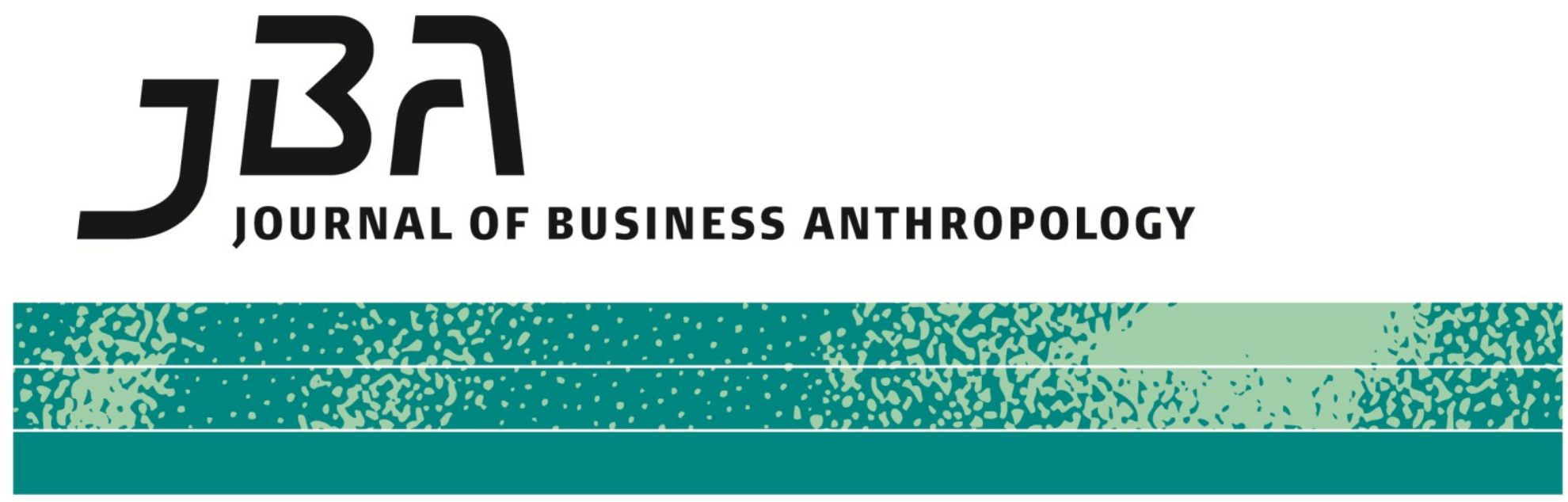

\title{
Studying Consumption Behaviour through Multiple Lenses: An Overview of Consumer Culture Theory
}

Annamma Joy \& Eric P. H. Li

\begin{abstract}
Since Miller's (1995) ground-breaking directive to the anthropology community to research consumption within the context of production, CCT has come of age, offering distinctive insights into the complexities of consumer behaviour. CCT positions itself at the nexus of disciplines as varied as anthropology, sociology, media studies, critical studies, and feminist studies; overlapping foci bring theoretical innovation to studies of human behaviours in the marketplace. In this paper, we provide asynthesis of CCT research since its inception, along with more recent publications. We follow the four thematic domains of research as devised by Arnould and Thompson (2005): consumer identity projects, marketplace cultures, the socio-historic patterning of consumption, and mass-mediated marketplace ideologies and consumers' interpretive strategies. Additionally, we investigate new directions for future connections between CCT research and anthropology.
\end{abstract}

\section{Keywords}

CCT, consumer identity projects, interpretive strategies, marketplace cultures, marketplace ideologies, socio-historic patterning of consumption

Page 1 of 33

JBA 1 (1): 141-173 Spring 2012

(c) The Author(s) 2012 ISSN $2245-4217$

www.cbs.dk/jba 


\section{Introduction}

Miller's exhortation (1995) to the anthropology community to research consumption in conjunction with production helped engender a sea change in consumer behaviour research, as disciplines increasingly melded, blurring their innate distinctions, to create new modes of research. A number of terms were deployed since the mid-eighties to describe this new approach: humanistic, naturalistic, interpretive, postmodern. An official term for this multi-disciplinary approach surfaced in 2005, introduced by Arnould and Thompson (2005) as "consumer culture theory." CCT has since become a shorthand acronym recognized in all major marketing journals. This paper provides an overview of CCT research, drawing from the Journal of Consumer Research, the Journal of Marketing, the Journal of Marketing Research, the Journal of Retailing, Consumption, Markets and Culture, and Qualitative Market Research, among others, with particular emphasis on seminal papers. Our paper is both a tribute to research already conducted, and a call to inspiration for further research, highlighting the underlying connection of linked study that enables researchers in anthropology and consumer behaviour, among other disciplines, to share common ground.

We begin with the obvious: what precisely is CCT? A method of assessing consumption apart from the usual frames of economics and psychology, CCT provides "a distributed view of cultural meaning" (Hannerz 1992: 16), one created, sustained, and transformed by larger social and cultural forces such as myths, narratives, and ideologies. Unfettered from stereotypical conceptions of broad social patterns, CCT nonetheless emerges from particular socio-economic systems, with the impact of globalization and market capitalism explicit in all CCT studies (Arnould and Thompson 2005: 869).

Since the late 70s, researchers have discussed the need for new perspectives in consumer research (Belk 1975; 1976). CCT has roots in such discussion, and more specifically in the naturalistic inquiry embodied by the Consumer Behaviour Odyssey Project in the mid-1980s, when a group of consumer researchers set off across the U.S. in an RV to conduct a multi-sited ethnographic field study (Anderson 1986; Belk 1976; 1986; 1987; Belk, Sherry, and Wallendorf 1988; Belk, Wallendorf, and Sherry 1989). The resulting literature sparked intense interest in consumer research that highlighted the cultural and social complexities of consumption (Graeber 2011). Often cited anthropologists in interpretive consumer research include Wilk (2006), Appadurai (1986; 1996), Arvidsson (2006), Callon, Méadel, and Rabeharisoa (2002), Douglas and Isherwood (1979), Mazzarella (2003), Miller (1987), Moeran (1996;

2006a), and Schor (1998). 
CCT illuminates the contextual, symbolic, and experiential aspects of consumption as they unfold across the consumption cycle, from acquisition to consumption and disposition (Arnould and Thompson 2005; McCracken 1986), encompassing frameworks that are interpretive, critical, emancipatory, and transformative. It interweaves disciplines as varied as anthropology, sociology, media studies, critical studies and feminist studies, among others (Arnould 1989; Belk 1988; 2010; Sherry and Camargo 1987; Diamond et al. 2009; Borghini et al, 2009; Joy, Sherry and Deschenes 2009; Joy, Sherry, Venkatesh and Deschenes 2009; Kozinets 2001; Marcoux 2009; Scott 1994a; 1994b; Sherry 1995; Schroeder 2006). Each research area provides a unique lens through which to study consumption behaviour; many researchers use multiple lenses to generate frameworks of understanding (Belk 2010; Epp and Price 2010; 2011; Humphreys 2010; Karababa and Ger 2011; Kozinets 2008; Ozanne and Saatcioglu 2008; Peñaloza and Barnhart 2011; Venkatesh, Joy, Sherry, and Deschenes 2010; Üstüner and Holt 2010). The success of the CCT tradition in contributing to theory and methodology in the field is evident in MacInnes and Folkes' (2010) identification of CCT as a sub-discipline in the field of consumer behaviour. They argue that consumer behaviour is, by its nature, a multidisciplinary phenomenon; adjoining disciplines can expand the intellectual horizons of the field, and add insight to theory building.

Arnould and Thompson (2005) identify four domains within which a number of researchers have made theoretical and methodological contributions. They are: (1) consumer identity projects, (2) marketplace cultures, (3) the socio-historical patterning of consumption, and (4) mass-mediated marketplace ideologies and consumers' interpretive strategies. In what follows, we will sustain those categorizations, allowing for the fact that some studies exhibit relevance within multiple categories. Additionally, we will summarize earlier findings, analyse current and new directions within each category, and identify potential future directions. While multiple methods are used by CCT researchers ethnographic approaches are dominant. Since the limitations of this overview are many, we urge the indulgence of our readers.

\section{Recent studies on consumer identity projects}

Identity via consumption is a topic shared by anthropologists (Miller 1995), sociologists (Featherstone 1991), and CCT researchers here in North America and abroad (Ahuvia 2005; Belk 1988; Cova and Elliot 2008: Caru and Cova 2008; Levy 1963; Sandikci and Ger 2010). Personobject relations are the focus of this theme, in all its complexity and 
variations. Objects are central to definitions of self, and in particular become extensions of the self (Ahuvia 2005; Belk 1988; Tian and Belk 2005) although such constructions are complex (Curasi, Price, and Arnould 2004; Kates 2004; Braun-LaTour, LaTour, and Zinkhan 2007), often riddled with ambivalence (Arsel and Thompson 2011), internal contradictions (Luedicke, Thompson, and Giesler 2010; Lastovicka and Fernandez 2005), and even pathology (Lastovicka and Sirianni 2011).

The impetus to look at commercial goods in the service of identity emerged with Belk's (1988) oft-quoted article on the extended self, and with Sherry's (1983) early, key article on gift-giving. CCT literature focuses on the economic and utilitarian motives of equivalence and equality as the springboard of giving behaviour, although the symbolic value of the gift continued to be dominant (Joy 2001; Sherry 1983; Sherry, McGrath and Levy 1992; Otnes, Lowrey, and Kim 1993).

Marcoux (2009) in particular shows how consumers use the market to free themselves from the straitjacket of social expectations and the sense of indebtedness. Other researchers have looked at the circulation of objects within a social network to illustrate commodity agency (Epp and Price 2010, Curasi, Price and Arnould 2004; Price, Arnould and Curasi 2000). By adopting Kopytoff's (1986) theory of singularization and concept of re-commodification, Epp and Price (2010) show how objects within a household become a key resource for the family to construct their individual, family, and social identities (see also Epp and Price 2008). Bradford (2009) examines the immaterial and material dimensions of gift -giving, and demonstrates how interacting parties create, sustain, or destroy the gifted assets.

Belk (2010) resuscitates the concept of the gift as an act of selfsacrifice through his seminal study of sharing. In a study on intracommunity gifting in New Orleans by Weinberger and Wallendorf (2012), the authors critique the existing literature on the gift with its focus on interpersonal relationships, building in multiple units to intra-community gifting. One outcome of such collective giving is a new sense of community, one defined with limited recourse to market ideology. While all such studies are centered on the moral economy, they also consider its intersection with the market economy.

A predominant theme in the identity project literature is the malleability of crafting identity. The ideology, at least in the industrialized world, that one is free to choose an individual mode of self-presentation has become widely accepted, certainly since McCracken's (1986) article on the movement of meaning notwithstanding multiple constraints (Foster 2007). Joy, Sherry, and Deschenes (2009) describe the many 
consumption meanings associated with virtual selves, ever-evolving and re-constructed at will.

Person-object relations can be viewed as an extension of the self (Belk 1988), or as disguise or sublimation of the self, such that the world is seen only from the inside out (Lastovicka and Sirianni 2011).

\section{Consumer identity and marketing myths}

The recent focus on examining how identity projects are constructed encompasses moral considerations. Through a study of adversarial consumer narratives relating to the Hummer brand, Luedicke, Thompson, and Giesler (2010) show that consumers' moralistic identity work begins with a cultural myth of the moral protagonist, which transforms their ideological beliefs into dramatic narratives of identity. Arsel and Thompson (2011) advance related theorizations delineating how sociocultural forces deter consumers from abandoning a consumption field associated with undesirable meanings. Epp and Price (2008) reveal how families draw on communication forms and use marketplace resources to manage interplays among individual, relational, and collective identities. Schau, Gilly, and Wolfinbarger (2009) illustrate an increase in the breadth and depth of identity-related consumption by the elderly, which they term a "consumer identity renaissance." Venkatesh, Joy, Sherry, and Deschenes (2010) investigate links between the aesthetics of luxury fashion, the body, and identity formation. Coupland (2005) throws a new spin on how brands need not stand out in people's lives, but rather can become invisible.

New research on material possession attachment that critiques the notion of the extended self is presented in Lastovicka and Sirianni's (2011) study. They argue that smitten individuals are often socially isolated, leaving object love as a form of compensation. Another take on object-person relations is provided by Fernandez and Lastovicka (2011) in their study of fetishes in contemporary consumption. Consumers use contagious and imitative magic to imbue their objects with unique auras. Persistence and its impact on consumers achieving goals, such as conceiving a child (the parent identity project), is the focus of a study by Fischer, Otnes, and Tuncay (2007). They show how cognition and cultural discourses jointly shape women's decision-making processes. Scientific rationalism, self-management, and fatalism similarly intervene.

Of particular interest to the notion of identity is Bahl and Milne's (2010) article. Instead of focusing on just one self, the authors maintain, researchers must consider consumer experience through the prism of multiple selves, and in the interaction of selves. While consumer 
researchers have examined multiple selves, especially when they are in conflict, they have not examined the dialogical nature of the self. The level of the self under scrutiny needs to be highlighted; the dialogical self provides a new framework for studying consumers at multiple levels.

\section{Global consumer identity projects}

Identity projects are complex for consumers in ideologically constraining cultures although similar constraints exist in the west as well (Tarlo2007). Sandikci and Ger (2010) show how stigmatized identity can become fashionable through co-optation with the market - i.e., when the market appropriates and commercializes subcultural practices (Schouten and McAlexander 1995; Thompson and Coskuner-Balli 2007). These authors study veiling among women in Turkey; the decision to wear a veil is an act of resistance and empowerment, as well as of escape.

Üstüner and Holt (2007), argue that in developing countries such as Turkey, identity projects of migrant women reveal a generational divide: while the migrant women themselves have created an identity that values living in squatter settlements in the city, their daughters have acculturated, and, stymied by economic limitations, are less content than their mothers.

Another take on global consumer culture and identity formation at a macro-level is provided by Dong and Tian (2009), who discuss how Chinese consumers employ Western brands to assert competing versions of Chinese national identity. Consumers use select discourses of EastWest relations, with the West viewed alternatively as liberator and oppressor, its brands as symbols of democratization or as domination.

Karababa and Ger (2011) provide a scintillating account of the formation of the consuming subject in Early Ottoman culture. They interpret the popular view of an actively self-identifying consumer, using an anthropological-historical approach to understand the formation of the consumer subject vis-à-vis market forces and institutions. Their study extends two important theoretical claims in CCT: (1) consumption resolves tensions between the pursuit of pleasure and morality (Belk, Ger and Askegaard 2003); and (2) market cultures are co-created through discursive negotiations and practices (Peñaloza 2000). Karababa and Ger (2011) show that the co-creation of market cultures includes an entire slate of actors - the state, religious institutions, and market-related intermediaries of various sorts.

Their analysis of how consumers resist the marketplace highlights that inclusion, instead of focussing on the impositions from the marketer (Maclaran and Brown 2005; Kozinets et al. 2004a; 2004b). One can look 
at the consumer as enjoying a certain level of freedom of choice in opposition to the marketer (Zwick, Denegri-Knott, and Schroeder 2007). Thus, the marketer and the consumer are not always in opposition.

Additional work in this context is also evidenced in the study by Cayla and Eckhardt (2008), who investigate how brand managers create regional Asian brands and markets through the construction of imagined Asian identities. These managers focus on the common experience of global experience, evoking a generic and hyper-urban experience infused with diverse cultural references. In turn, these Asian brands contribute to the creation of an imagined Asia as modern and multicultural.

Another view on the topic of identity constructed through global consumption is provided by Bardhi, Eckhardt, and Arnould's (2012) study of global nomadic consumers. This research counters Belk's (1988) study that possessions are used to extend the self while anchoring identity in space, as consumers configure the world into a place of belonging. Global nomadism by its nature involves de-territorialization. During ongoing travel, relationships to objects are temporary and situational, and possessions are appreciated for their instrumental use value and immateriality. Such individuals do not wish to acculturate - they prefer enduring mobility and detachment from national geography.

\section{Consumer identity and post-assimilationist research}

Recent studies demonstrate that ethnic identification is a complex and dynamic process, mediated by market logic and influenced by sociocultural contexts. Askegaard and Ozcaglar-Toulouse (2011) note that ethnicity is a key resource in consumer identity projects, and that the study of ethnic identification should therefore demonstrate the complexity of the social processes involved in the formation of contemporary ethnoscapes (217). Luedicke (2011) also builds on the notion of consumer acculturation. His model suggests that a focus on identity construction, acculturation agents (media, market agents, and

political institutions) and boundary crossings would provide a richer and deeper understanding of acculturation.

Migrant groups and their consumption patterns open up new possibilities for understanding global consumer culture. While research on such topics in the 1980s, 1990s, and early 2000s (Oswald 1999;

Peñaloza 1994; Peñaloza and Gilly 1999; Stayman and Deshpande 1989) provided insights into how acculturation occurs, new research focuses on how consumers negotiate their cultural identities through consumption (Bardhi, Ostberg and Bengtsson 2010). In their research on the Greenlandic consumer acculturation process, Askegaard, Arnould, and Kjeldgaard (2005) introduce an oscillation model to illustrate the 
dynamic and reflexive nature of consumer identities in a transnational context. They argue for a spectrum of hybrid identities constructed by immigrant consumers, one affected by socio-historical factors, political ideology, and market-mediated cultural practices. Jafari and Goulding (2008) introduce the notion of the "torn self" to express how Iranian immigrants suffered from the negotiations between the two cultural ideologies in the U.K. Chytkova's (2011) study of Romanian women in Italy examines how the negotiation of gender roles of immigrant women is an important component of consumer acculturation.

Areas ripe for future research include power relationships between the dominant group (mainstream marketers and consumers), minority consumers, and entrepreneurs in a multi-cultural marketplace. Also worthy of attention: boundary creation, management strategies, and public policies that shape immigrant acculturation. In sum, the breadth and depth of cultural categories and cultural principles have been mined to produce important insights into how socio-historical forces impact consumption.

\section{Consumption environments and consumer experiences}

Although the concept of experience is implicit in the consumer identity projects, it was articulated more clearly in several subsequent articles. In their landmark article on hedonic consumption, Hirschman and Holbrook (1982) had earlier critiqued the then popular notion of the consumer as a rational decision-maker. Thompson, Locander, and Pollio's (1989) research returns the focus to consumer experience (Thompson 1997). Joy and Sherry (2003) study aesthetic consumption and aesthetic experiences. They highlight the value of an imaginative, embodied, and emplaced self in the pursuit of aesthetic pleasure. A raft of papers detailed the rich experiences created through marketplace interactions, such as thematized spaces (Maclaran and Brown 2005; Kozinets 2002a; Kozinets et al. 2004a; 2004b); including Las Vegas (Belk 2000); Nike Town (Peñaloza 1998; Sherry 1998); rodeos (Peñaloza 2001), and ESPN zones (Kozinets et al. 2004a; 2004b). Diamond et al.'s (2009) study of the American Girl phenomenon provides a holistic understanding of the socio-cultural construction of an intensely emotional brand. Researchers have also explored the construction of experience in liminal spaces such as festivals and carnivals (Kates and Belk 2001; Belk and Costa 1998; and Kozinets 2002a). Cotte and LaTour (2009) examine how gambling behaviours and experience changed after the introduction of online gambling. Overall, sensory and experiential aspects of consumption have taken center stage in most of the CCT studies described above. 


\section{Identity, public policy and transformative consumer research}

Consumer researchers such as Ozanne and Saaatcioglu (2008) have a transformational view of society, advocating participatory action research (PAR) for improving lives. PARS agenda calls for (1) a reflexive understanding of the posionality of the researcher, (2) an evaluation of the goal of social change by new criteria (3) the creation of more sophisticated theories of power and social change to improve consumer welfare (4) the development of more personalized methods of research and (5) the dissemination of knowledge that is culturally appropriate and feasible.

Transformative consumer research is a relatively new approach in understanding consumer identity, as researchers have highlighted the link between public policy and consumer response (Mick 2008; Ozanne 1992; Ozanne \& Saatcioglu 2008). Disadvantaged or vulnerable consumers have been studied (Hill 1991; Hill and Stamey 1990). Adkins and Ozanne (2005) study low-literate consumers, Wong and King (2008) research patients with chronic diseases, Kjeldgaard and Askegaard (2006) study children and adolescent consumers, and Crockett and Wallendorf (2004) focus on minority consumers. Moisio and Beruschvalli (2010) explore the supportive community of Weight Watchers. The dark side of consumption - obsessive and compulsive behaviours, such as uncontrolled credit card debt, alcoholism, and other addictions - has also received attention (Bernthal, Crockett, and Rose 2005; Henry 2010; Peñaloza and Barnhart 2011).

A different issue taken by Henry (2010) examines consumer rights and responsibilities in the context of credit card users in Australia. He asks how consumers view their own rights and responsibilities. His query ties in with the broader theme of the role of moral responsibility in markets consisting of relatively disconnected consumers. Surprisingly, the research shows that both Libertarian and liberal consumers equally valorize the mythic ideal of autonomy. The nuances of consumer responses suggest an ideological perspective, revealing a broad range of often competing beliefs that mute sympathy, high functioning, and activism (Henry 2010: 683).

CCT research on consumer identity projects has received significant attention for good reason: its contributions are substantial.

\section{Marketplace cultures}

In research focussing on marketplace cultures, consumers are viewed primarily as culture producers, rather than merely as culture bearers. Arnould and Thompson (2005) ask how consumers forge collective or 
community identity, and how they share common value through interaction with the marketplace. How does the emergence of consumption as a dominant practice reconfigure cultural blueprints for action and interpretation, and vice versa? Under this rubric fall area studies (Joy 2001), subcultures of consumption (Schouten and McAlexander 1995; Muñiz and Schau 2005), and a culture of consumption (Kozinets 2001). In the context of major socio-cultural transformations that have eroded traditional bases for sociality, consumers search for ways to collectively identify and participate in rituals of solidarity. Often such searching occurs online (Cova and Pace 2006; Kozinets 2002b; Kozinets et al. 2010). These experiential subcultures have used consumption as a raison d'être for fostering community -whether fleeting or permanent. In some instances, these groups define themselves in opposition to dominant lifestyles and sensibilities. Worthy of note are how such subcultures present themselves - through displays of localized cultural capital, and through skill in combining and reworking the pool of symbolic resources shared by group members (Kozinets 2001)

\section{Brand communities and consumer resistance}

Schau, Muñiz, and Arnould (2009) examine collective value creation processes within brand communities. They identify four themes of value creating practices: social networking, impression management, community engagement, and brand use. They note that corporations can derive significant benefit via creatively exploiting, and, to a degree, ceding control to willing customers, which in turn increases consumer brand engagement, thereby strengthening the brand community. Consumer involvement and engagement are also the topic of research by Kozinets et al. (2010) who identify the importance of the network co-production model. New social media marketing platforms offer brands broad-based communication strategies with micro-targeted appeals, which are themselves ever-expanding avenues ripe for exploration.

Thompson and Arsel (2004) develop the concept of a hegemonic brandscape. Goulding, Shankar, Elliott, and Canniford (2009) argue that the practice of clubbing is a marketplace culture that is legally sanctioned, even as it supports a range of illegal practices that are easier to control and concurrently economically productive (fortuitously enough for club owners). Rather than viewing clubbing as a reaction to consumer alienation, or an act of countercultural ideological resistance, these practices are seen as part of everyday life.

While Marcoux's (2009) previously referenced study examines how people use the market to free themselves from oppressive relations within the gift economy, Belk (2010), also previously referenced, shows 
how sharing is very much a part of families and communities, albeit one being slowly eroded by market commoditization. What Belk labels "sharing in" calls for research on "sharing out" - a phenomenon studied by Visconti, Sherry, Borghini, and Anderson (2010). They extend understanding of consumer agency beyond the domain of privately owned and consumed goods, by unpacking the dialogic agentic confrontation between street artists and dwellers through their different ideologies of public place consumption. Geisler's (2006) study of file sharing via Napster critiques the dyadic model of the gift, and elaborates on the distributed model exemplified by file sharing. However, social distinctions, norms of reciprocity, and rituals characterize such gift systems as well.

Thompson and Coskuner-Balli (2007) develop further the concept of brand communities by focusing on a polit-brand community, the Community Supported Agricultural community (CSA). Despite their ideologically framed perspectives, CSA members are still part of the larger whole that supports global consumer culture. As a re-embedded consumption community, CSA offers consumers reaffirming experiences of emotional immediacy, confidence in outcomes, direct participatory involvement, and personal engagement that are difficult to replicate in a dis-embedded polit-brand community whose relational networks and real political consequences are diffused.

As referenced earlier, Dong and Tian (2009) focus on Chinese consumers employing Western brands to assert competing versions of Chinese national identity; the authors account for not only the socioeconomic/socio-cultural, but also political factors. The complexities of marketplace cultures are evident in how youth cultures are a manifestation of transnational, market-based ideology, evident through a dialectic between structures of common difference (Wilk 1995), and the adaptation and objectification of these structures in local contexts referred to as glocalization, a term encompassing the local impact of global consumer culture (Askegaard, Arnould and Kjeldgaard 2005; Kjeldgaard and Askegaard 2006). These authors argue that coconstitutive relationships between globalization and everyday consumption practices are an important framework for understanding consumer behaviour. Cayla and Eckhardt (2008) examine how brands help forge new ways for consumers to think beyond their specific nationality to an "imagined community."

Branding managers and other market-related intermediaries contribute to creating a regional consciousness, especially in Asia. Cayla and Eckhardt build on Peñaloza's (2001) idea that marketers play a key role in structuring these positions. They also further the view of brands as 
stories in consumers' collective imaginations. By showing how brands can help forge inter-connectedness, the authors encourage us to assess the resulting stream of research from a global perspective. They extend the prevailing view of globalizing consumer culture, recognizing that globalization is far more than a Western-oriented one- or even two-way street-it is a multiplicity of streets, from Hong Kong, Beijing, Singapore, and many other urban hubs, with cultures freely intertwined.

Overall, Miller's (1995) call for focusing on both production and consumption ushered in a new era - one vibrant with fresh insights - in CCT research.

\section{The socio-historical patterning of consumption}

Arnould and Thompson (2005) summarize how institutional social structures such as gender, ethnicity, class, and community help structure consumption and vice versa (Bristor and Fischer 1993: Cova 1997; Dobscha and Ozanne 2001; Fischer and Arnold 1990; Hill 1991; Holt 1997; 1998; 2002, 2004; Schroeder and Borgerson 1998; Wallendorf and Reilly 1983). They ask bluntly: what is a consumer society, and how is it constituted and sustained?

\section{Institutionalization of consumption ideologies}

More recently, Üstüner and Thompson (2012) provide an understanding of consumer status games, by focusing on marketplace performances (especially those situated in a longer term, consumer-service provider relationship) that enable consumers to use economic, social, and cultural capital. Specifically, the authors study longer-term multifaceted status games via the hair stylist industry in Turkish cities, in which the service providers - typically men - have little or no education, but have skills essential to delivering service to highly educated and affluent customers typically women. Both groups vie for dominance and control. By virtue of their wealth and ongoing patronage, clients wield class-based authority over the stylists, and, within the microcosm of the salon, are simultaneously free of the patriarchal norms prevalent in Turkish society. Humphreys (2010), in her study of the legitimization of casino gambling in the U.S., uses institutional theory to define how the market normalizes, rationalizes, and legitimizes gambling.

Overall, the breadth and depth of cultural categories and principles have been mined to produce important insights into how socio-historical forces impact consumption. 


\section{Mass-mediated marketplace ideologies and consumers' interpretive strategies}

Mass-mediated marketplace ideologies fall within the purview of CCT (McQuarrie and Mick 1992; 1996; 1999; Rinallo and Basuroy 2009; Scott 1990; Sherry and Camargo 1987; Stern 1993). Consumer ideology refers to the systems of meaning that channel and reproduce consumers' thoughts and actions, thereby defending dominant interests in society, a field of study examined in critical theory and media studies. Arnould and Thompson (2005) ask what normative messages commercial media transmit regarding consumption. How do consumers make sense of these messages and formulate critical responses? Consumers are viewed as interpretive agents whose meaning creation activities range from tacitly embracing the dominant representations of consumer identity and lifestyle ideals portrayed in advertising and mass media, to those consciously deviating from such ideological instructions. Often, this line of inquiry surveys criticism of capitalism and marketing as social institutions.

Kozinets' (2008) study of technology and ideology grappled with the complexities of understanding both technology and ideology and their interpenetration as expressed in the narratives of consumers who move among various categories, such as Techtopian ideology (technology as progress, albeit with moral overtones); the green luddite ideology (technology as fear-inducing, unnecessary, and unsustainable); the work machine ideology (technology as central to economic growth), and finally the Techspressive ideology (technology as an extension of people's identities based on pleasure). Kozinet's (2010) book based on his (2002b) seminal article on Netnography, (ethnography on line) has had wide appeal, and has spurred further research (Munar 2010; Bilgram, Bartl and Biel 2011).

Another line of research into anti-consumption movements and ideology is represented in the work of Varman and Belk (2009). The antiCoca-Cola sentiment expressed by villagers in North India reflects attempts by locals to evoke the nationalist Swadeshi movement in India, introduced by Gandhi fifty years earlier. The revised version of Swadeshi, while focusing on materialism, took a different tack--protesters used spatial politics to create strong feelings of "us" vs. "them." The corporation and its various products are framed negatively (with CocaCola sold in India deemed inferior to local soft drinks because of its high pesticide content); the renewed nationalism, rather than serving as a reversal to the old ideology of nationhood, instead indicates the power of consumers. 
Through the medium of advertising, Zhao and Belk (2008) examine China's ongoing evolution from communism to a consumer society. The authors assess how advertising has appropriated a dominant anti-consumerist ideology to justify its promotion of consumption, how it has bridged the apparent ideological tensions between communism and consumerism, and what structural patterns of representation have facilitated this ideological transition in advertising (Zhao and Belk 2008: 231-32). Their research underscores the idea that the marketplace is not only alive with cultural mythologies, but also saturated with political ideologies. Ironically, as China changed from a capitalist to a socialist system, and then moved toward market socialism, its advertising drew on a rich tradition of political propaganda to recast China as a consumer society.

The broad framework used in the focus on the impact of media on consumers is borrowed from anthropology and media studies. Such studies typically use semiotic and literary analysis to search for symbolic meanings, the messages in popular cultural texts, and the rhetorical strategies employed to make such ideological messages appealing (Escalas and Stern 2003; Hirschman 1990; Holbrook and Grayson 1986; McQuarrie and Mick 1996; Phillips and McQuarrie 2010; Scott 1990, 1994a, 1994b). These studies question purely psychological assessments of advertising and media, and underscore the importance of considering the cultural contexts within which decisions are made. By decoding and deconstructing mass-mediated marketplace ideologies, CCT theorists reveal the ways in which capitalist cultural production systems seduce consumers into particular lifestyles and their associated products, with consumers as willing participants.

Finally, Phillips and McQuarrie (2010) investigate why women engage with advertisements in which the product itself is framed, as opposed to the more typical images of airbrushed young women or enticing landscapes featuring a given product. Their findings revealed that one group looked at advertisements as fictional representations, imagining themselves transported into another world. Others responded to advertising images as art, and appreciated their beauty. The resulting greater engagement, by either means, led to a more meaningful consumer experience.

Reviewing the established research, both over the past twenty years and particularly in the last seven, during which much invaluable research debuted, one sees clearly that CCT research is concerned with cultural meanings, socio-historic influences, and social dynamics that shape consumer experience and identities in the many, messy contexts of everyday life (Firat and Venkatesh 1995). CCT researchers use multiple 
data sources and triangulate methods: what consumers experience is neither unified and monolithic, nor transparently rational. Most consumers' lives are constructed around multiple realities shaped by consumption experiences (Arnould and Thompson 2005).

\section{Discussion: the nexus between anthropology and CCT}

In 1995, Miller had already noted imminent changes in the study of consumer culture: (1) production and consumption would be, and should be, studied concurrently rather than in isolation, (2) the relation of firstworld local consumption models and their impact on production in thirdworld contexts would be of deep importance, (3) the study of major shifts in first-world consumption and their cosmological foundations, for example, the green movement and associated practices, would necessarily increase, (4) the transformation of shopping into a major instrument for the enactment of a commitment to family values would be increasingly studied as well, with the modern Christmas and its foundational myth pointing to a fundamental dialectic in modernity between the freedom represented by commodities, and the continued desire for normative sociability represented by kinship; and (5) the intrinsic link between kinship and consumption would be increasingly relevant, as evidenced by recent studies of consumption activities centered on home and family.

In response to Miller's (1995) suggestions, the concept of marketplace cultures, which include brand communities and practices (Cova and Pace 2006; Brown, Kozinets, and Sherry 2003; Muñiz and O'Guinn 2000; McAlexander, Schouten, and Koenig 2002; Muñiz and Schau 2005; Schau, Muñiz, and Arnould 2009) and collective/family identities (Epp and Price 2008; 2010) can be seen as evidence of the application of this model of co-production in CCT research. Major shifts in first-world consumption and their cosmological foundations, witnessed in studies of green consumption - precisely as Miller (1995), above, predicted - are emerging in the CCT literature (Maarkula and Moisander 2012; Moisander 2007). Belk's (1989; 2010) studies of Christmas consumption and sharing, respectively, embody this line of research, along with studies on the gift by Marcoux (2009). Finally, Fischer, Otnes, and Tuncay's (2007) article on pursuing parenthood, described earlier, addresses the links between kinship and consumption.

In his recent article on the semiotics of brand, Manning (2010) summarizes a group of studies on branding that are inspiring to CCT researchers. Wilk's (2006) study of bottled water is a good example of how branding strategies condense a social ontology shot through with contradictory attitudes of nature and technology, the state and the 
market, public and private spheres, and first- and third-world economies. Wilk (2006: 320) calls for a symbiotic relationship between branding/marketing and anti-commercial resistance and the rhetoric of individuality, family, morality, and religion. Foster (2007) likewise argues that if the reflexive destabilization of products (as an outcome of cocreation) concerns marketers, it also concerns consumers. Meneley (2004; 2007) pinpoints the disparities in products/brands from particular regions of the world. The positive image of the Mediterranean and its healthful diet, along with its pastoral associations, imbues Tuscan extra virgin olive oil as an object of desire. In contrast, extra virgin olive oil grown in the West Bank - associated with strife and poverty - has no such positive associations. (Meneley 2007). The associative framing easily trumps reality.

Such metaphoric consumption of alterity, Manning (2010) reports, is matched by metonymic alterity - the desire for actual objects from elsewhere, e.g., labels and containers of Western goods, often detached from use value, came to be self-valuable mediums of contact with the imaginary West in the USSR (Yurchak 2006). Üstüner and Holt's (2010) study of the Western-oriented upper-class consumers and the local-oriented rich consumers in Turkey explores this contradictory phenomenon in detail.

Arvidsson's (2005) study of brandscapes elaborates on the idea of atmospherics, extended to the scripting and styling of a service interaction, including the consumer, who co-produces the experience. Schau, Muñiz, and Arnould's (2009) study of brand practices describes how consumers co-create experiences for themselves, even as the regulating and appropriating component of brand management is also clear. Kozinets et al.'s (2010) study of corporate use of social media communication details how such communication regulates while simultaneously enabling consumer creativity.

Virtual identity is another fruitful area of research. de Waal Malefyt (2009) studies companies that gather consumer data via technology while interacting with customers. While Kozinets et al. (2010) and Schau, Muñiz, and Arnould (2009) recommend actions to be taken by corporate brand managers, the authors' respective studies do not explore how such action might unfold - an area ripe for further exploration.

Although Appadurai's (1990) opinions on globalization have been fleshed out sufficiently in the marketing and consumer literature, his view on the "imagined communities" of the nation-state being replaced by "diaspora public spheres" has been critiqued by Cayla and Eckhardt (2009). However, his view that media and migration together produce an enormous degree of instability in the creation of selves and identities 
needs greater empirical substantiation in CCT and anthropology. The new areas of global consumer culture studies are just beginning to tap into these processes (Askegaard and Kjeldgaard 2002; Kjeldgaard and Askegaard 2006).

The structure of experience in anthropology (Throop 2008) is another area growing in relevance. Despite the massive amount of work done in anthropology (e.g., Durkheim, Turner, and Geertz, among others), experience is, as Throop states, often embedded in the narrative and taken for granted as a construct. In their study on consumers' lived experience, Thompson, Locander, and Pollio (1989) suggest that the meaning of an experience is always situated in the current experiential context, and is coherently related to the ongoing project of the life world. Their suggestion has found resonance in other studies of extraordinary experiences (e.g., Cristel and Levy 2011; Celsi, Rose and Leigh 1993; Arnould and Price 1993; Thompson 1997; Joy and Sherry 2003; Tumbat and Belk 2011). Achrol and Kotler (2011: 37) argue that consumer experiences have taken center stage in digital age of information. More work needs to be done on temporality, embodiment, and emplacement of selves in experiential context.

\section{The meaning of consumption and identity}

In recent years, easily the two most provocative articles exploring anthropology and CCT have been Graeber's "Consumption” (2011), referenced earlier, and Leve's "Identity” (2011). Graeber urges fellow researchers to critically examine the very concept of consumption. Since consumers take pleasure in, and partially craft their identities through, their consumption. Graeber (2011: 490) argues that, in denouncing consumption, researchers risk simultaneously denouncing that which makes lives meaningful. He raises an important issue: why are all forms of self-expression and enjoyment reduced to a blanket notion of 'consumption'? Rather than conceiving of consumption as a purely analytical term, Graeber approaches it as, inescapably, an ideology, one deserving of - even requiring - a critical approach.

Lauren Leve (2011) likewise questions the uncritical use of the term "identity" - one central to our culturalist approach to consumption (Carrier 2004. Using Macpherson's (1962) discussion of possessive individualism, she reimagines for a modern age his argument that possessive individualism, emphasizing the individual as proprietor of self, transforms the logic of the labour market into a theory of the self. The move toward a service-based economy, she argues, has created a shift in focus from production to consumption. Drawing on the Buddhist emphasis on seeing the continuity of self or material objects as illusions, 
Leve counsels anthropologists to challenge the concept of "identity," and to neither perpetuate nor naturalize a concept that itself requires explanation.

\section{CCT and consumer sub-disciplines}

MacInnes and Folkes (2010) argue that consumer behaviour can be seen as a multi-disciplinary field with sub-disciplines advancing the field.

Rather than being separated into discrete research camps, the subdisciplines are unified by a core concern with acquisition, consumption, and disposal of marketplace entities. Indeed, specialization has resulted in expansion in the number of sub-fields (Arnould and Thompson 2005). Moreover, MacInnes and Folkes (2010) argue that specialization can fuel novel insights and energize the field. In our examination of the CCT literature, we have identified important articles that would classify as new sub-field hybrids. As early as 1989, Belk, Wallendorf, and Sherry argued in their article on the sacred and the profane that the concept of consumer involvement, as defined in consumer research, was too limiting in terms of understanding person object relations. Since then, implicitly or explicitly, most articles in the CCT tradition have provided one form of critique of the information processing or behaviour decision theory (Firat and Venkatesh 1995; Hirschman and Holbrook 1982; Holbrook and Grayson 1986; Holbrook and Hirschman 1982). Allen's (2002) study explicitly critiques choice theories in consumer behaviour, and offers an alternate approach that supplements decision-making processes. Cristel and Levy (2011) use a cultural approach in discussing repeat consumption as an extraordinary experience filled with the emotional luxury of delight, novel sensations, and intellectual insight, showing that hedonic re-consumption is not merely habitual, addictive, or even ritualistic - the three main approaches to the study of re-consumption to date.

Business anthropologists such as Moeran (2005; 2006b), and Sunderland and Denny (2007) provide new perspectives on the inclusion of employees, managers, consumers, and others in corporate organizations, collaboratively creating market cultures. In the field of consumer research, a different twist in the identity projects (also leading to hybrids within the field of business) is provided by Press and Arnould (2011) in their study of organizational identification. They describe how employees are involved in sense making, and how the three processes of epiphany, emulation, and exploration forge identification with an organization. While still in its nascent stages, such applications of CCT research within organizations, or collaborative efforts with scholars of organizational behaviour and strategic management, are needed, and 
could lead to hybrid understandings with other sister disciplines, such as finance or neuro-psychology.

The study of consumer welfare is broadly aligned with analyzing issues of ethics in consumer behaviour and marketing. Studies that examine moral aspects include those of Borgmann (2000), Commuri and Gentry (2005), Hill and Stamey (1990), Karababa and Ger (2011), Sandikci and Ger (2010), and Thompson and Troester (2002). Green consumerism is researched by Moisander and Pesonen (2002). Joy, Sherry, Venkatesh, Wang, and Chan (2012) assess issues of sustainability within the context of fast fashion and luxury fashion brands. The discursive confusion endemic to sustainable consumption, given the multiple and ever-evolving discourses involved, is raised by Markulla and Moisander (2012). As Achrol and Kotler (2012: 37) warn:

"Marketing...over-fulfills materialistic wants and under-serves nonmaterial wants." Given the reality of fast-diminishing resources and increasing consumption in developing contexts (Arnould 1989; Bonsu and Belk 2003), consumers and producers must develop a model of sustainable consumption within a global commons.

In a period of cultures and consumption patterns both ever more fragmented and simultaneously ever more interconnected, CCT research, coupled with the critical approach endorsed by Graeber and Leve, affords an opportunity for cross-disciplinary study capable of shining light on areas long in darkness. The time for reflection afforded by CCT research is past due: new such research is eagerly awaited.

\section{References}

Achrol, Ravi and Phillip Kotler 2012 "Frontiers of the Marketing Paradigm in the Third Millennium," Journal of the Academy of Marketing Science, (40), 350-52.

Adkins, Natalie Ross and Julie L. Ozanne 2005 "The Low Literate Consumer," Journal of Consumer Research, 32 (June), 93-105.

Ahuvia, Aaron C. 2005 "Beyond the Extended Self: Loved Objects and Consumers' Identity Narratives," Journal of Consumer Research, 32 (June), 171-84.

Allen, Douglas 2002 "Toward a Theory of Consumer Choice as Sociohistorically Shaped Practical Experience: The Fits-Like-a-Glove (FLAG) Framework," Journal of Consumer Research, 28 (March), 515-32. 
Anderson, Paul F. 1986 "On Method in Consumer Research: A Critical Relativist Perspective," Journal of Consumer Research, 13 (September), 155-73.

Appadurai, Arjun 1986 "Introduction: Commodities and the Politics of Value," in The Social Life of Things: Commodities in Cultural Perspective, (ed.) Arjun Appadurai, Cambridge: Cambridge University Press, 3-63.

---- 1990 "Disjuncture and Difference in the Global Cultural Economy," in Theory, Culture, Society, (ed.) Mike Featherstone, London: Sage, 295-310.

---- 1996 Modernity at Large: Cultural Dimensions of Globalization.

Minneapolis: University of Minnesota Press.

Arnould, Eric J. 1989 "Toward a Broadened Theory of Preference Formation and the Diffusion of Innovations: Cases from Zinder Province, Niger Republic," Journal of Consumer Research, 16 (September), 239-67.

----- and Linda L. Price 1993 "River Magic: Extraordinary Experience and the Extended Service Encounter," Journal of Consumer Research, 20 (June), 24-45.

---- and Craig J. Thompson 2005 “Consumer Culture Theory (CCT): Twenty Years of Research," Journal of Consumer Research, 31 (March), 868-82.

Arsel, Zeynep and Craig J. Thompson 2011 "Demythologizing Consumption Practices: How Consumers Protect Their Field-Dependent Identity Investments from Devaluing Marketplace Myths," Journal of Consumer Research, 37 (February), 791-806.

Arvidsson, Adam 2005 “Brands: A Critical Perspective," Journal of Consumer Culture, 5 (2), 235-58.

Askegaard, Søren, Eric J. Arnould, Dannie Kjeldgaard 2005 "Postassimilationist Ethnic Consumer Research: Qualifications and Extensions," Journal of Consumer Research, 32 (June), 160-70.

----- and Dannie Kjeldgaard 2002 "The Water Fish Swim In? Relations between Culture and Marketing in the Age of Globalization," in Perspectives on Marketing Relationships, (eds.) Thorbjørn Knudsen, Søren Askegaard, and Niels Jørgensen, Copenhagen: Thomson, 13-35.

----- and Nil Ozcaglar-Toulouse 2011 "Still Crossing Borders: Migration, Consumption, and Markets," Consumption Markets and Culture, 14 (September), 217-22.

Bahl, Shalini and George R. Milne 2010 "Talking to Ourselves: A Dialogical Exploration of Consumption Experiences," Journal of Consumer Research, 37 (June), 176-95. 
Bardhi, Fleura, Jacob Ostberg, and Anders Bengtsson 2010 "Negotiating Cultural Boundaries: Food, Travel and Consumer Identities," Consumption Markets and Culture, 13 (June), 133-57.

----- Giana M. Eckhardt, and Eric J. Arnould 2012 “Liquid Relationship to Possessions," Journal of Consumer Research, forthcoming.

Belk Russell W. 1975"Situational Variables and Consumer Behavior" Journal of Consumer Research 2 (3); 157-164.

---- 1976 "It's the Thought That Counts: A Signed Digraph Analysis of Gift-Giving," Journal of Consumer Research, 3 (December), 155-62.

----- 1986 "What Should ACR Want to Be When It Grows Up?" in Advances in Consumer Research, 13, (ed.) Richard J. Lutz, Provo, UT: Association for Consumer Research, 423-24.

----- 1987 “Presidential Address: Happy Thought," Advances in Consumer Research, 14, (ed.) Melanie Wallendorf and Paul Anderson, Provo, UT: Association for Consumer Research, 1-4.

----- 1988 "Possessions and the Extended Self," Journal of Consumer Research, 15 (September), 139-68.

---- 1989 “Materialism and the Modern U.S. Christmas" In Interpretive Consumer Research, (ed.) Elizabeth C. Hirschman, Provo, UT: Association for Consumer Research, 115-35.

----- 2000 "May the Farce be with You: On Las Vegas and Consumer Infantalization," Consumption Markets and Culture, 4 (2), 101-24.

----- 2010 “Sharing," Journal of Consumer Research, 36 (February), 715-34.

----- and Janeen Arnold Costa 1998 "The Mountain Myth: A Contemporary Consuming Fantasy," Journal of Consumer Research, 25 (December), 21840 .

-----, Güliz Ger, and Søren Askegaard 2003 "The Fire of Desire: A Multisited Inquiry into Consumer Passion," Journal of Consumer Research, 30 (December), 326-52.

-----, John F. Sherry, and Melanie Wallendorf 1988 "A Naturalistic Inquiry into Buyer and Seller Behaviour at a Swap Meet," Journal of Consumer Research, 14 (March), 449-70.

-----, Melanie Wallendorf, and John F. Sherry 1989 "The Sacred and the Profane in Consumer Behavior: Theodicy on the Odyssey," Journal of Consumer Research, 16 (June), 1-39.

Bernthal, Matthew J., David Crockett, Randall L. Rose 2005 "Credit Cards as Lifestyle Facilitators," Journal of Consumer Research, 32 (June), 130-45. 
Bilgram,Volker, M. Bartl, and Stefan Biel 2011 "Getting Closer to the Consumer: How Nivea Co-creates New Products" Marketing Review St. Gallen, (1), 34-40.

Bonsu, Samuel K. and Russell W. Belk 2003 “Do Not Go Cheaply into That Good Night: Death Ritual Consumption in Asante Ghana," Journal of Consumer Research, 30 (June), 41-55.

Borghini, Stefania, Nina Diamond, Robert V. Kozinets, Mary Ann McGrath, Albert M. Muñiz, and John F. Sherry 2009 "Why Are Themed Brandstores So Powerful? Retail Brand Ideology at American Girl Place," Journal of Retailing, 85 (September), 363-75.

Borgmann, Albert 2000 "The Moral Complexion of Consumption," Journal of Consumer Research, 26 (March), 418-22.

Bradford, Tonya Williams 2009 "Intergenerationally Gifted Asset Dispositions," Journal of Consumer Research, 36 (June), 93-111.

Braun-LaTour, Kathryn A., Michael S. LaTour, and George M. Zinkhan (2007), "Using Childhood Memories to Gain Insight into Brand Meaning," Journal of Marketing, 71 (April), 45-60.

Bristor, Julia M. and Eileen Fischer 1993 "Feminist Thought: Implications for Consumer Research," Journal of Consumer Research, 19 (March), 51836.

Brown, Stephen, Robert Kozinets, and John F. Sherry (2003), "Teaching Old Brands New Tricks: Retro Branding and the Revival of Brand Meaning," Journal of Marketing, 67 (July), 19-33.

Callon Michel, Cécile Méadel, and Vololona Rabeharisoa 2002 "The Economy of Qualities," Economy and Society, 31 (2), 194-217.

Carù, Antonella and Bernard Cova 2008 "Small Versus Big Stories in Framing Consumption Experiences," Qualitative Market Research: An International Journal, 11 (2), 166-76.

Carrier James 2004 "Consumption and Anthropology: Limits to Culture?" paper presented at. the Conference at the Zentrum für Interdisziplinäre Forschung in Bielefeld, Germany, February 26-28.

Cayla, Julien and Giana M. Eckhardt 2008 "Asian Brands and the Shaping of a Transnational Imagined Community," Journal of Consumer Research, 35 (August), 216-30.

Celsi, Richard, Randall Rose, and Thomas Leigh 1993 "An Exploration of High-Risk Leisure Consumption through Skydiving," Journal of Consumer Research, 20 (June), 1-21. 
Chytkova, Zuzana 2011 “Consumer Acculturation, Gender, and Food: Romanian Women in Italy between Tradition and Modernity," Consumption Markets and Culture, 14 (September), 267-91.

Commuri, Suraj and James W. Gentry 2005 "Resource Allocation in Households with Women as Chief Wage Earners," Journal of Consumer Research, 32 (September), 185-95.

Cotte, June and Kathryn A. LaTour 2009 "Blackjack in the Kitchen: Understanding Online versus Casino Gambling," Journal of Consumer Research, 35 (February), 742-58.

Coupland, Jennifer Chang 2005 "Invisible Brands: An Ethnography of Households and the Brands in Their Kitchen Pantries," Journal of Consumer Research, 32 (June), 106-18.

Cova, Bernard 1997 "Community and Consumption: Towards a Definition of the 'Linking Value' of Product or Services," European Journal of Marketing, 31 (3-4), 297-316.

----- and Richard Elliott 2008 "Everything You Always Wanted to Know About Interpretive Consumer Research but Were Afraid to Ask," Qualitative Market Research: An International Journal. 11(2), 121-29.

----- and Stefano Pace 2006 "Brand Community of Convenience Products: New Forms of Customer Empowerment - the Case 'My Nutella The Community'," European Journal of Marketing, 40 (9/10), 1087 - 1105.

Cristel, Antonia Russell and Sidney J. Levy 2011 “The Temporal and Focal Dynamics of Volitional Reconsumption: A Phenomenological Investigation of Repeated Hedonic Experiences," Journal of Consumer Research, forthcoming.

Crockett, David and Melanie Wallendorf 2004 "The Role of Normative Political Ideology in Consumer Behavior," Journal of Consumer Research, 31 (December), 511-28.

Curasi, Carolyn, Linda Price, and Eric Arnould 2004 "How Individuals' Cherished Possessions Become Families' Inalienable Wealth," Journal of Consumer Research, 31 (December), 609-22.

Diamond, Nina, John F. Sherry Jr., Albert M. Muñiz Jr., Mary Ann McGrath, Robert V. Kozinets, and Stefania Borghini 2009 "American Girl and the Brand Gestalt: Closing the Loop on Sociocultural Branding Research," Journal of Marketing, 73 (May), 118-34.

Dobscha, Susan and Julie L. Ozanne 2001 "An Eco-feminist Analysis of Environmentally Sensitive Women Using Qualitative Methodology: The Emancipatory Potential of an Ecological Life," Journal of Public Policy and Marketing, 20 (Fall), 201-14. 
Dong, Lily and Kelly Tian 2009 "The Use of Western Brands in Asserting Chinese National Identity," Journal of Consumer Research, 36 (October), 504-23.

Douglas, Mary and Baron Isherwood 1979 The World of Goods: Toward an Anthropology of Consumption, New York: Basic

de Waal Malefyt, Timothy 2009 "Understanding the Rise of Consumer Ethnography: Branding Techno-methodologies in the New Economy," American Anthropologist, 3 (2), 201-10.

Epp, Amber M. and Linda L. Price 2008 "Family Identity: A Framework of Identity Interplay in Consumption Practices," Journal of Consumer Research, 35 (June), 50-70.

-----2010 “The Storied Life of Singularized Objects: Forces of Agency and Network Transformation," Journal of Consumer Research, 36 (February), 820-37.

----- 2011 “Designing Solutions Around Customer Network Identity Goals," Journal of Marketing, 75 (March), 36-54.

Escalas, Jennifer Edson and Barbara B. Stern 2003 "Sympathy and Empathy: Emotional Responses to Advertising," Journal of Consumer Research, 29 (March), 566-78.

Featherstone, Mike 1991 Consumer Culture and Postmodernism, Thousand Oaks, CA: Sage.

Fernandez, Karen V. and John L. Lastovicka 2011 "Making Magic: Fetishes in Contemporary Consumption," Journal of Consumer Research, 38 (August), 278-99.

Firat, A. Fuat and Alladi Venkatesh 1995 "Liberatory Postmodernism and the Reenchantment of Consumption," Journal of Consumer Research, 22 (December), 239-67.

Fischer, Eileen and Stephen J. Arnold 1990 "More than a Labour of Love: Gender Roles and Christmas Gift Shopping," Journal of Consumer Research, 17 (December), 333-45.

-----, Cele C. Otnes, and Linda Tuncay 2007 “Pursuing Parenthood: Integrating Cultural and Cognitive Perspectives on Persistent Goal Striving," Journal of Consumer Research, 34 (December), 425-40.

Foster, Robert 2007 The Work of the New Economy: Brands and Value Creation," Cultural Anthropology, 22 (4), 707-31.

Goulding, Christina, Avi Shankar, Richard Elliott, and Robin Canniford 2009 "The Marketplace Management of Illicit Pleasure," Journal of Consumer Research, 35 (February), 759-71. 
Graeber David 2011 “Consumption” Current Anthropology, 52 (4), 489511.

Hannerz, Ulf 1992 Cultural Complexity, New York: Columbia University Press.

Henry, Paul C. 2010 "How Mainstream Consumers Think about Consumer Rights and Responsibilities," Journal of Consumer Research, 37 (December), 670-87.

Hill, Ronald Paul 1991 "Homeless Women, Special Possessions, and the Meaning of Home: An Ethnographic Case Study," Journal of Consumer Research, 18 (December), 298-310.

----- and Mark Stamey 1990 "The Homeless in America: An Examination of Possessions and Consumption Behaviours," Journal of Consumer Research, 17 (December), 303-21.

Hirschman, Elizabeth C. 1990 "Secular Immortality and the American Ideology of Affluence," Journal of Consumer Research, 17 (June), 31-42.

----- and Morris Holbrook 1982 "Hedonic Consumption: Emerging Concepts, Methods, and Propositions," Journal of Marketing, 46 (Summer), 92-101.

Holbrook, Morris B. and Mark W. Grayson 1986 "The Semiology of Cinematic Consumption: Symbolic Consumer Behaviour in Out of Africa," Journal of Consumer Research, 13 (December), 374-81.

----- and Elizabeth C. Hirschman 1982 "The Experiential Aspects of Consumption: Consumer, Fantasies, Feelings, and Fun," Journal of Consumer Research, 9 (September), 132-40.

Holt, Douglas B. 1997 "Poststructuralist Lifestyle Analysis: Conceptualizing the Social Patterning of Consumption," Journal of Consumer Research, 23 (March), 326-50.

---- 1998 “Does Cultural Capital Structure American Consumption?” Journal of Consumer Research, 25 (June), 1-26.

----- 2002 "Why Do Brands Cause Trouble? A Dialectical Theory of Consumer Culture and Branding," Journal of Consumer Research, 29 (June), 70-90.

---- 2004 How Brands Become Icons: The Principles of Cultural Branding, Cambridge, MA: Harvard Business School Press.

Humphreys, Ashlee 2010 "Semiotic Structure and the Legitimation of Consumption Practices: The Case of Casino Gambling," Journal of Consumer Research, 37 (October), 490-510. 
Jafari, Alikbar and Christina Goulding 2008 "We Are Not Terrorists! UKBased Iranians, Consumption Practices, and the "Torn Self," Consumption Markets and Culture, 11 (2), 73-91.

Joy, Annamma 2001 "Gift Giving in Hong Kong and the Continuum of Social Ties," Journal of Consumer Research, 28 (September), 239-56.

----- and John F. Sherry 2003 "Speaking of Art as Embodied Imagination: A Multi-Sensory Approach to Understanding Aesthetic Experience," Journal of Consumer Research, 30 (September), 259-82.

-----, John F. Sherry, Alladi Venkatesh, Jeff Wang, and Ricky Chan 2012 "Fast Fashion, Sustainability, and the Ethical Appeal of Luxury Brands," Fashion Theory, forthcoming.

-----, John F Sherry, and Jonathan Deschenes 2009 “Conceptual Blending in Advertising," Journal of Business Research, 62 (1), 39-49.

-----, John F Sherry, Alladi Venkatesh, and Jonathan Deschenes, 2009 "Perceiving Images, Telling Tales: A Visual and Verbal Analysis of the Meanings of the Internet," Journal of Consumer Psychology, 19: 556-566.

Karababa, Emİnegül and Güliz Ger 2011 "Early Modern Ottoman Coffeehouse Culture and the Formation of the Consumer Subject," Journal of Consumer Research, 37 (February), 737-60.

Kates, Steven M. 2004 "The Dynamics of Brand Legitimacy: An Interpretive Study in the Gay Men's Community," Journal of Consumer Research, 31 (September), 455-64.

----- and Russell W. Belk 2001 "The Meanings of Lesbian and Gay Pride Day: Consumption through Resistance and Resistance to Consumption," Journal of Contemporary Ethnography, 30 (August), 392-429.

Kjeldgaard, Dannie and Søren Askegaard 2006 "The Glocalization of Youth Culture: The Global Youth Segment as Structures of Common Difference," Journal of Consumer Research, 33 (September), 231-47.

Kopytoff, Igor 1986 "The Cultural Biography of Things: Commoditization as Process," in The Social Life of Things, (ed.) Arjun Appadurai, Cambridge: Cambridge University Press, 64-94.

Kozinets, Robert V. 2001 "Utopian Enterprise: Articulating the Meaning of Star Trek's Culture of Consumption," Journal of Consumer Research, 28 (June), 67-89.

---- 2002a "Can Consumers Escape the Market? Emancipatory Illuminations from Burning Man" Journal of Consumer Research, 29 (June), 20-38. 
---- 2002b "The Field Behind the Screen: Using Netnography for Marketing Research in Online Communities," Journal of Marketing Research, 39 (February), 61-72.

---- 2008 “Technology/Ideology: How Ideological Fields Influence Consumers' Technology Narratives," Journal of Consumer Research, 34 (April), 865-81.

----- 2010 Netnography: Doing Ethnographic Research Online, London: Sage.

-----, Kristine de Valck, Andrea C. Wojnicki, and Sarah J. S. Wilner 2010 "Networked Narratives: Understanding Word-of-Mouth Marketing in Online Communities," Journal of Marketing, 74 (March), 71-89.

-----, John F. Sherry Jr., Diana Storm, Adam Duhachek, Krittinee Nuttavuthist, and Benet DeBerry-Spence 2004a "Ludic Agency and Retail Spectacle," Journal of Consumer Research, 31 (December), 658-72.

-----, John F. Sherry Jr., Diana Storm, Adam Duhachek, Krittinee Nuttavuthisit and Benet De-Berry Spence 2004b "Gendered Behaviour in a Male Preserve: Role Playing at ESPN Zone Chicago," Journal of Consumer Psychology, 14 (192), 151-58.

Lastovicka, John L. and Karen V. Fernandez 2005 “Three Paths to Disposition: The Movement of Meaningful Possessions to Strangers," Journal of Consumer Research, 31 (March), 813-23.

---- and Nancy J. Sirianni 2011 "Truly, Madly, Deeply: Consumers in the Throes of Material Possession Love," Journal of Consumer Research, 38 (August), 323-42.

Leve Lauren 2011 "Identity" Current Anthropology, 52 (4), 512-535. Levy, Sidney J. 1963 "Symbolism and Life Style," in Toward Scientific Marketing, (ed.) Stephen A. Greyser, Chicago: American Marketing Association, 140-50.

Luedicke, Marius K. 2011 "Consumer Acculturation Theory: (Crossing) Conceptual Boundaries," Consumption Markets and Culture, 14 (September), 223-44.

-----, Craig J. Thompson, and Markus Giesler 2010 "Consumer Identity Work as Moral Protagonism: How Myth and Ideology Animate a BrandMediated Moral Conflict," Journal of Consumer Research, 36 (April), 101632.

MacInnis, Deborah J. and Valerie S. Folkes 2010 “The Disciplinary Status of Consumer Behaviour: A Sociology of Science Perspective on Key Controversies," Journal of Consumer Research, 36 (April), 899-914. 
Maclaran, Pauline and Stephen Brown 2005 "The Center Cannot Hold: Consuming the Utopian Marketplace," Journal of Consumer Research, 32 (September), 311-23.

Macpherson Crawford, B., 1962 The Political Theory of Possessive Individualism: Hobbes to Locke, Oxford: Clarendon.

Manning, Paul 2010 "The Semiotics of Brand," Annual Review of Anthropology, 39, 33-49.

Marcoux, Jean-Sébastien 2009 "Escaping the Gift Economy," Journal of Consumer Research, 36 (December), 671-85.

Markkula, Annu and Johanna Moisander 2012 "Discursive Confusion and Sustainable Consumption: A Discursive Perspective on the Perplexity of the Market Place Knowledge," Journal of Consumer Policy, 35 (1), 105-25. Mazzarella, William 2003 "Very Bombay: Contending with the Global in an Indian Advertising Agency," Cultural Anthropology, 18 (1), 33-71.

McAlexander, James H., John W. Schouten, and Harold Koenig 2002 "Building Brand Community," Journal of Marketing, 66 (January), 38-54.

McCracken, Grant 1986 “Culture and Consumption: A Theoretical Account of the Structure and Movement of the Cultural Meaning of Consumer Goods," Journal of Consumer Research, 13 (June), 71-84.

McQuarrie, Edward F. and David Glen Mick 1992 “On Resonance: A Critical Pluralistic Inquiry into Advertising Rhetoric," Journal of Consumer Research, 19 (September), 180-97.

----- 1996 "Figures of Rhetoric in Advertising Language," Journal of Consumer Research, 22 (March), 424-36.

---- 1999 “Visual Rhetoric in Advertising: Text-Interpretative, Experimental, and Reader-Response Analyses," Journal of Consumer Research, 26 (June), 37-54.

Meneley, Anne 2004 "Extra-virgin olive oil and slow food," Anthropologica, 46 (2), 165-76.

---- 2007 “Like an Extra-Virgin," American Anthropologist, 109 (4): 67887.

Miller, Daniel 1987 Material Culture and Mass Consumption, Oxford: Blackwell.

---- 1995 “Consumption and Commodities,” Annual Review of Anthropology, 24, 141-61.

Mick, David Glen 2008 "The Moment and Place for a Special Issue," Journal of Consumer Research, 35 (3), 377-79. 
Moeran, Brian 1996 A Japanese Advertising Agency: An Anthropology of Media and Markets, Honolulu: University of Hawaii Press.

---- 2005 The Business of Ethnography: Strategic Exchanges, People and Organizations, Oxford: Berg.

---- 2006a "More Than Just a Fashion Magazine," Current Sociology, 54

(5) $725-44$.

---- 2006b Ethnography at Work, Oxford: Berg.

Moisio, Risto and Mariam Beruchashvili 2010 "Questing for Well-Being at Weight Watchers: The Role of the Spiritual-Therapeutic Model in a Support Group," Journal of Consumer Research, 36 (February), 857-75.

Moisander, Johanna 2007 "Motivational Complexity of Green Consumerism," International Journal of Consumer Studies, 31(4), 404-09.

----- and Sinikka Pesonen 2002 "Narratives of Sustainable ways of Living: Constructing the Self and the Other as a Green Consumer," Management Decision, 40 (4), 329-42.

Munar, Ana Maria 2010 "Digital Exhibitionism: The Age of Exposure," Culture Unbound, 2, 401-22.

Muñiz, Albert and Thomas C. O'Guinn 2000 "Brand Communities," Journal of Consumer Research, 27 (March), 412-32.

----- and Hope Schau 2005 "Religiosity in the Abandoned Apple Newton Brand Community," Journal of Consumer Research, 31 (March), 737-47.

Oswald, Laura R. 1999 "Culture Swapping: Consumption and the Ethnogenesis of Middle-Class Haitian Immigrants," Journal of Consumer Research, 25 (March), 303-18.

Otnes, Cele, Tina M. Lowrey, and Young Chan Kim 1993 "Gift Selection for Easy and Difficult Recipients: A Social Roles Interpretation," Journal of Consumer Research, 20 (September), 229-44.

Ozanne, Julie L. 1992 "The Role of Consumption and Disposition during Classic Rites of Passage: The Journey of Birth, Initiation, and Death," Advances in Consumer Research, 19, (ed.) John F. Sherry and Brian Sternthal, Provo, UT: Association for Consumer Research, 396-403.

----- and Bige Saatcioglu 2008 "Participatory Action Research," Journal of Consumer Research, 35 (October), 423-39.

Peñaloza, Lisa 1994 "Atravesando Fronteras/Border Crossings: A Critical Ethnographic Study of the Consumer Acculturation of Mexican Immigrants," Journal of Consumer Research, 21 (June), 32-53. 
---- 1998 "Just Doing It: A Visual Ethnographic Study of Spectacular Consumption Behavior at Nike Town," Consumption, Market and Culture, 2 (4), 337-400.

----- 2000 “The Commodification of the American West: Marketers' Production of Cultural Meanings at a Trade Show," Journal of Marketing, 64 (October), 82-109.

---- 2001 "Consuming the American West: Animating Cultural Meaning at a Stock Show and Rodeo," Journal of Consumer Research, 28 (December), 369-98.

----- and Michelle Barnhart 2011 "Living U.S. Capitalism: The Normalization of Credit/Debt," Journal of Consumer Research, 38 (December), 743-62.

----- and Mary Gilly 1999 "Marketer Acculturation: The Changer and the Changed," Journal of Marketing, 63 (July), 84-104.

Phillips, Barbara J. and Edward F. McQuarrie 2010 "Narrative and Persuasion in Fashion Advertising," Journal of Consumer Research, 37 (October), 368-92.

Press, Melea and Eric J. Arnould 2011 "How Does Organizational Identification Form? A Consumer Behavior Perspective," Journal of Consumer Research, 38 (December), 650-66.

Price, Linda, Eric Arnould, and Carolyn Curasi 2000 "Older Consumers' Disposition of Valued Possessions," Journal of Consumer Research, 27 (September), 179-201.

Rinallo, Diego and Suman Basuroy 2009 "Does advertising spending influence media coverage of advertiser?" Journal of Marketing, 73 (November), 33-46.

Sandikci, Özlem and Güliz Ger 2010 "Veiling in Style: How Does a Stigmatized Practice Become Fashionable?" Journal of Consumer Research, 37 (June), 15-36.

Schau, Hope Jensen, Mary C. Gilly, and Mary Wolfinbarger 2009 "Consumer Identity Renaissance: The Resurgence of Identity-Inspired Consumption in Retirement," Journal of Consumer Research, 36 (August), 255-76.

-----, Albert M. Muñiz, Jr., and Eric J. Arnould 2009 “How Brand Community Practices Create Value," Journal of Marketing, 73 (September), 30-51.

Schor, Juliet 1998 The Overspent American: Up-scaling, Downshifting, and the New Consumer, New York: Basic Books. 
Schouten, John and James H. McAlexander 1995 "Subcultures of Consumption: An Ethnography of the New Bikers," Journal of Consumer Research, 22 (June), 43-61.

Schroeder, Jonathan E. 2006 "Critical Visual Analysis" in Handbook of Qualitative Research methods in Marketing, (ed.) Russ Belk, Aldershot, UK: Edward Elgar, 303-21.

----- and Janet L. Borgerson 1998 "Marketing Images of Gender: A Visual Analysis," Consumption, Markets, and Culture, 2 (2), 161-201.

Scott, Linda M. 1990 “Understanding Jingles and Needledrop: A Rhetorical Approach to Music in Advertising," Journal of Consumer Research, 17 (September), 223-36.

---- 1994a "The Bridge from Text to Mind: Adapting Reader-Response Theory to Consumer Research," Journal of Consumer Research, 21 (December), 461-80.

----- 1994b "Images in Advertising: The Need for a Theory of Visual Rhetoric," Journal of Consumer Research, 21 (September), 252-73.

Sherry, John F. 1983 “Gift Giving in Anthropological Perspective," Journal of Consumer Research, 10 (September), 157-68.

---- 1995 Contemporary Marketing and Consumer Behaviour: An Anthropological Source book, Thousand Oaks, CA: Sage.

----- 1998 Servicescapes: The Concept of Place in Contemporary Markets, Chicago: NTC Business Books.

----- and Eduardo Camargo 1987 “'May Your Life Be Marvelous': English Language Labeling and the Semiotics of Japanese Promotion," Journal of Consumer Research, 14 (September), 174-88.

-----, Mary Ann McGrath, and Sidney Levy 1992 “ Disposition of the Gift and Many Unhappy Returns," Journal of Retailing, 68 (1), 40-65.

Stayman, Douglas M. and Rohit Deshpande 1989 "Situational Ethnicity and Consumer Behaviour," Journal of Consumer Research, 16 (December), 361-71.

Stern, Barbara B. 1993 "Feminist Literary Criticism and the Deconstruction of Ads: Overview and Illustrative Analysis," Journal of Consumer Research, 19 (March), 556-66.

Sunderland, Patricia L. and Rita M. Denny 2007 Doing Anthropology in Consumer Research, Walnut Creek, CA: Left Coast Press.

Tarlo Emma 2007"Islamic Cosmopolitanism: The Sartorial Biographies of Three Muslim Women in London," Fashion Theory. Vol.11 Issue2/3.p143172. 
Thompson, Craig J. 1997 "Interpreting Consumers: A Hermeneutical Framework for Deriving Marketing Insights from the Texts of Consumers' Consumption Stories," Journal of Marketing Research, 34 (4), 438-55.

----- and Zeynep Arsel 2004 “'The Starbucks Brandscape and Consumers' (Anticorporate) Experiences of Glocalization," Journal of Consumer Research, 31 (December), 631-42.

----- and Gokcen Coskuner-Balli 2007 “Countervailing Market Responses to Corporate Co-optation and the Ideological Recruitment of Consumption Communities," Journal of Consumer Research, 34 (August), 135-52.

-----, William B. Locander, and Howard R. Pollio 1989 "Putting Consumer Experience Back into Consumer Research: The Philosophy and Method of Existential-Phenomenology," Journal of Consumer Research, 16 (September), 133-46.

----- and Maura Troester 2002 "Consumer Value Systems in the Age of Postmodern Fragmentation: The Case of the Natural Health Microculture," Journal of Consumer Research, 28 (March), 550-71. Throop, Jason 2008 "Articulating Experience," Anthropological Theory. 3(2), 219-24.

Tian, Kelly and Russell W. Belk 2005 "Extended Self and Possessions in the Workplace," Journal of Consumer Research, 32 (September), 297-310.

Tumbat, Gülnur and Russell W. Belk 2011 "Marketplace Tensions in Extraordinary Experiences," Journal of Consumer Research, 38 (June), 4261.

Üstüner, Tuba and Douglas B. Holt 2007 “Dominated Consumer Acculturation: The Social Construction of Poor Migrant Women's Consumer Identity Projects in a Turkish Squatter," Journal of Consumer Research, 34 (June), 41-56.

----- 2010 "Toward a Theory of Status Consumption in Less Industrialized Countries," Journal of Consumer Research, 37 (June), 37-56.

----- and Craig J. Thompson 2012 "How Marketplace Performances Produce Interdependent Status Games and Contested Forms of Symbolic Capital," Journal of Consumer Research, 38 (February), 796-814.

Varman, Rohit and Russell W. Belk 2009 "Nationalism and Ideology in an Anticonsumption Movement," Journal of Consumer Research, 36 (December), 686-700.

Venkatesh, Alladi, Annamma Joy, John F. Sherry and Jonathan Deschenes 2010 "The Aesthetics of Luxury Fashion, Body and Identify Formation," Journal of Consumer Psychology, 20 (4), 459-70. 
Visconti, Luca M., John F. Sherry, Stefania Borghini, and Laurel Anderson 2010 "Street Art, Sweet Art? Reclaiming the "Public" in Public Place," Journal of Consumer Research, 37 (October), 511-29.

Wallendorf, Melanie and Michael D. Reilly 1983 “Ethnic Migration, Assimilation, and Consumption," Journal of Consumer Research, 10 (December), 292-302.

Weinberger, Michelle F. and Melanie Wallendorf 2012 "Intracommunity Gifting at the Intersection of Contemporary Moral and Market Economies," Journal of Consumer Research, forthcoming.

Wilk, Richard 1995 "Learning to Be Local in Belize: Global Systems of Common Difference," in Worlds Apart: Modernity through the Prism of the Local, (ed.) Daniel Miller, London: Routledge, 110-31.

---- 2006 "Bottled Water: the Pure Commodity in the Age of Branding," Journal of Consumer Culture, 6 (3), 303-25.

Wong, Nancy and Tracey King 2008 "The Cultural Construction of Risk Understandings through Illness Narratives," Journal of Consumer Research, 34 (February), 579-94.

Yurchak, Alexei 2006 Everything Was Forever, Until It was No More: The Last Soviet Generation, Princeton University Press.

Zhao, Xin and Russell W. Belk 2008 "Politicizing Consumer Culture: Advertising's Appropriation of Political Ideology in China's Social Transition," Journal of Consumer Research, 35 (August), 231-44.

Zwick, Detlev, Janice Denegri-Knott, and Jonathan Schroeder 2007 "The Social Pedagogy of Wall Street: Stock Trading as Political Activism?" Journal of Consumer Policy, 30 (3), 177-99.

Annamma Joy is Professor of Marketing at the University of British Columbia and has been a visiting scholar at The Hong Kong University of Science and Technology, China-Europe International Business School and SDA Bocconi, Milan among others. Her research interests are primarily in the area of consumer behaviour and branding. She has published widely in consumer behaviour and marketing journals such as the Journal of Consumer Research, Journal of Consumer Psychology, International Journal of Research in Marketing, Journal of Cross-cultural Psychology, Journal of Economic Psychology, Consumption, Markets and Culture. Annamma.Joy@ubc.ca

Eric Ping Hung LI is an instructor at the University of British Colombia and holds a PhD from Schulich School of Business, York University, Toronto. eric.li@ubc.ca 